\title{
PENJADWALAN PRODUKSI DENGAN MEMPERTIMBANGKAN UKURAN LOT TRANSFER BATCH UNTUK MINIMASI MAKESPAN KOMPONEN ISOLATING COCK DI PT PINDAD
}

\author{
${ }^{1}$ Vita Ardiana Sari, ${ }^{2}$ Dida Diah Damayanti, ${ }^{3}$ Widia Juliani \\ Program Studi Teknik Industri, Fakultas Rekayasa Industri, Universitas Telkom \\ 1vitardianasari@gmail.com, ${ }^{2}$ didadiah@gmail.com, ${ }^{3}$ widiajuliani@yahoo.com
}

\begin{abstract}
Abstrak- PT PINDAD adalah salah satu perusahaan BUMN (Badan Usaha Milik Negara) bagian industri manufaktur dalam bidang Alat Utama Sistem Persenjataan (Alutsista) dan produk komersial. Salah satu produk dalam bidang transportasi adalah Air Brake System terdiri dari beberapa assembly, salah satunya assembly Isolating Cock yang terdiri dari Rumah Isolating Cock, Flens, Penutup, dan Baut Ventilasi. Makespan dan batasan waktu penyelesaian order membuat perusahaan berusaha memenuhi pesanan tepat waktu. Usaha yang dilakukan perusahaan adalah menambah shift kerja. Ukuran lot transfer batch yang digunakan mempengaruhi makespan. Makespan yang panjang dikarenakan penyelesaian order menggunakan aturan First Come First Served tanpa memperhatikan ukuran lot transfer batch. Dalam mencapai tujuan minimasi makespan, maka diusulkan penjadwalan dengan algoritma Campbell, Dudek, dan Smith (CDS) dengan ukuran lot transfer batch komponen Rumah Isolating Cock sublot satu 6 unit dan sublot dua 6 unit, komponen Flens sublot satu 9 unit dan sublot dua 3 unit, komponen Penutup sublot satu 4 unit dan sublot dua 8 unit, serta komponen Baut Ventilasi sublot 12 unit, dilakukan lima kali pengulangan sehingga total 60 unit Isolating Cock dapat minimasi makespan dari 117 jam atau 18 shift kerja menjadi adalah 45,8 jam atau 8 shift sehingga menghemat waktu penyelesaian sebesar $60,85 \%$.
\end{abstract}

Kata Kunci : CDS, Lot splitting, Transfer batch

\section{PENDAHULUAN}

PT PINDAD (Persero) merupakan perusahaan BUMN (Badan Usaha Milik Negara) yang bergerak dalam bidang Alutsista (Alat Utama Sistem Persenjataan) dan produk komersial. Salah satu divisi di PT PINDAD adalah Divisi Mesin Industri dan Jasa (MIJAS) yang menghasilkan produk-produk komersial antara lain mesin listrik, sistem pengereman kereta api, peralatan kapal laut, dan jasa pemesinan. MIJAS menaungi Departemen Pemesinan
(DEPSIN) yang bertugas membuat seluruh komponen produk PT PINDAD [1].

Air Brake System adalah sistem pengereman kereta api yang digunakan pada kereta penumpang terdiri dari beberapa assembly, salah satunya yaitu Isolating Cock. Komponen-komponen produk Isolating Cock, yaitu Rumah Isolating Cock, Flens, Penutup, dan Baut Ventilasi. Isolating Cock berfungsi untuk menutup saluran pada gerbong/kereta paling akhir. Isolating Cock diproduksi berdasarkan make to order atau barang dikerjakan ketika ada pesanan. Customer PT. PINDAD untuk produk Isolating Cock adalah PT. INKA. Pada tahun 2014 PT PINDAD mendapat order Isolating Cock sebanyak 600 pasang. Setiap pasang terdiri atas Isolating Cock kanan dan Isolating Cock kiri, sehingga jumlah order seluruhnya adalah 1.200 unit.

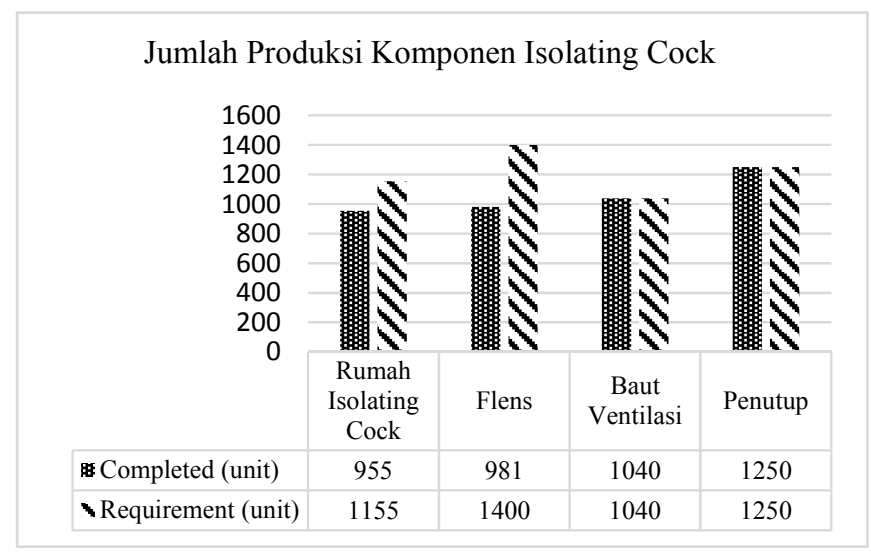

Gambar 24 Jumlah produksi komponen Isolating Cock untuk order PT INKA

Gambar 1 menunjukkan jumlah produksi komponen Isolating Cock dan dibandingkan dengan kebutuhan. Hal tersebut menunjukkan bahwa komponen Rumah Isolating Cock dan Flens mengalami keterlambatan. Setiap menjelang 
akhir due date seringkali timbul masalah penumpukan beban sisa pengerjaan pesanan yang masih banyak. Upaya yang dilakukan perusahaan untuk memenuhi order adalah dengan penambahan shift kerja. Saat ini PT PINDAD secara normal menggunakan dua shift kerja. Namun PT PINDAD menyediakan tiga shift untuk hari kerja dan waktu lembur pada hari Sabtu dan Minggu. Penambahan shift kerja dan jam lembur berpengaruh terhadap biaya yang dikeluarkan perusahaan. Peningkatan jumlah produksi yang dapat dilakukan adalah dengan melakukan penjadwalan ulang terhadap komponen-komponen Isolating Cock. Oleh karena itu dibutuhkan suatu perbaikan dalam penjadwalan yang digunakan pada proses produksi komponen-komponen Isolating Cock. Dengan adanya perbaikan dalam penjadwalan tersebut, diharapkan dapat mengurangi makespan sehingga bisa mengurangi jam lembur.

\section{METODE PENELITIAN}

Penelitian ini bertujuan untuk memperoleh jadwal produksi komponen Isolating Cock dengan makespan yang paling pendek dengan pengaturan ukuran lot transfer batch untuk mengurangi jam lembur. Penjadwalan adalah pengurutan pembuatan/pengerjaan produk secara menyeluruh yang dikerjakan pada beberapa buah mesin [2]. Lot adalah sebuah kuantitas dari sebuah item baik itu pembelian, produksi, atau transportasi. Sebuah lot dipindahkan atau ditransfer dari satu stasiun kerja ke stasiun kerja lain disebut transfer batch. Salah satu cara untuk mengurangi lead time produksi dan WIP untuk sebuah process batch adalah menggunakan lot splitting dan memindahkan lot tersebut pada operasi selanjutnya dengan transfer batch yang lebih kecil [3].

Gambar 2 mengenai konsep penelitian. Data yang digunakan adalah data order, data jenis dan jumlah mesin, data waktu proses, data waktu setup mesin, data proses routing, dan data waktu kerja karyawan. Kemudian melakukan penjadwalan menggunakan algoritma CDS. Urutan tersebut digunakan untuk menentukan urutan job yang digunakan untuk produksi komponen Isolating Cock dengan mempertimbangan lotsize transfer batch. Makespan yang paling pendek digunakan sebagai usulan penjadwalan.

\section{HASIL DAN PEMBAHASAN}

A. Tahap Pengumpulan Data

Pengumpulan data dilakukan dengan cara mengobservasi DEPSIN, wawancara dengan karyawan bagian DEPSIN dan pengambilan data sekunder langsung dari bagian Production Control. Data yang diperoleh adalah:

a. Data order meliputi No. order, nama komponen, jumlah, start date, dan finish date. Tabel I menunjukkan data order pada tahun 2014.

TABEL 7

DATA ORDER

\begin{tabular}{|c|c|c|c|c|}
\hline No. Order & Deskripsi & $\begin{array}{c}\text { Quantity } \\
\text { (unit) }\end{array}$ & $\begin{array}{c}\text { Basic start } \\
\text { date }\end{array}$ & $\begin{array}{c}\text { Basic finish } \\
\text { date }\end{array}$ \\
\hline 32200001421 & $\begin{array}{c}\text { Isolating } \\
\text { Cock }\end{array}$ & 1,200 & $15-09-14$ & $31-12-14$ \\
\hline
\end{tabular}

b. Data mesin yang digunakan untuk produksi komponen-komponen Isolating Cock, meliputi jenis mesin, jumlah mesin, dan kode mesin

c. Data waktu proses yang dihitung melalui pengamatan

d. Data waktu setup meliputi setup fixture, setup tools, dan setup benda kerja.

e. Data proses routing

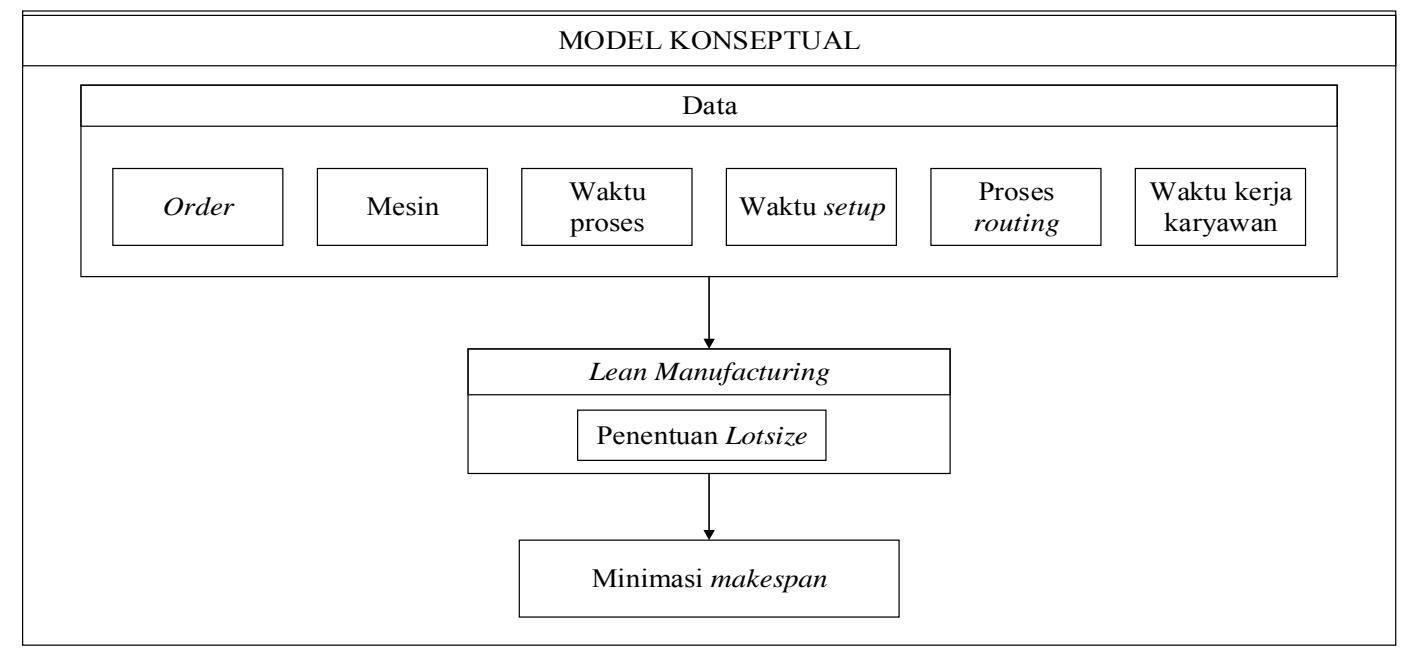

Gambar 25 Model konseptual 
TABEL II

DATA ROUTING

\begin{tabular}{|c|c|c|c|c|c|c|c|}
\hline \multirow{3}{*}{$\begin{array}{c}\text { Nama } \\
\text { Komponen }\end{array}$} & Proses & Operasi & $\begin{array}{c}\text { Kode } \\
\text { Mesin }\end{array}$ & $\begin{array}{c}\text { Setup } \\
\text { fixture } \\
\text { (menit) }\end{array}$ & $\begin{array}{c}\text { Setup } \\
\text { tools } \\
\text { (menit) }\end{array}$ & $\begin{array}{c}\text { Setup } \\
\text { benda kerja } \\
\text { (menit) }\end{array}$ & $\begin{array}{c}\text { Waktu } \\
\text { Baku } \\
\text { (menit) }\end{array}$ \\
\hline \multirow{5}{*}{ Rumah IC } & Bubut 1 & O-1A & L08 & 6.15 & 3.1 & 3.05 & 14.73 \\
\cline { 2 - 9 } & Bubut 2 & O-2A & L09 & 2.95 & 0.8 & 3.1 & 3.48 \\
\cline { 2 - 9 } & Bubut 3 & O-3A & L04 & 2.95 & 2.8 & 3.1 & 9.09 \\
\cline { 2 - 9 } & Bubut 4 & O-4A & L10 & 2.95 & 3.7 & 3.1 & 10.63 \\
\cline { 2 - 9 } & Bubut 5 & O-5A & L11 & 2.95 & 2.9 & 3.1 & 8.11 \\
\cline { 2 - 9 } & Bor & O-6A & D01 & 0.3 & 0.35 & 1.05 & 26.11 \\
\hline \multirow{5}{*}{ Flens } & Bubut 1 & O-1B & L04 & 2.95 & 1 & 3.05 & 5.42 \\
\cline { 2 - 9 } & Bubut 2 & O-2B & L10 & 2.95 & 3.9 & 3.05 & 16.27 \\
\cline { 2 - 9 } & Bor & O-3B & D01 & 0.3 & 0.35 & 0.95 & 10.69 \\
\cline { 2 - 8 } & Frais & O-4B & M06 & 0.3 & 0.6 & 0.95 & 1.47 \\
\hline \multirow{2}{*}{ Penutup } & Bubut 1 & O-1C & L10 & - & 0.7 & 1.05 & 3.3 \\
\cline { 2 - 9 } & Bubut 2 & O-2C & L11 & - & 2.9 & 1.1 & 8.65 \\
\hline Baut Ventilasi & Bubut 1 & O-1D & L08 & 2.95 & 3 & 3.05 & 6.94 \\
\hline
\end{tabular}

Tabel II menunjukkan data routing yang berisi data mesin yang digunakan untuk produksi, data waktu baku untuk setiap proses, dan waktu setup untuk setiap proses.

a. Data waktu kerja karyawan, yaitu tersedia tiga shift kerja terdiri dari 6,5 jam kerja/shift.

B. Tahap Pengolahan Data

1. Penjadwalan Order Kondisi Existing

Pada penjadwalan kondisi existing, mendahulukan order yang diterima. Pada bulan Agustus sampai Desember 2014 terdapat empat order yang bersamaan yaitu Rumah IC, Flens, Penutup, dan Baut Ventilasi. Ukuran lot yang digunakan pada saat ini ditunjukkan Tabel III.

Waktu yang digunakan untuk produksi 60 komponenkomponen Isolating Cock adalah 18 shift kerja. Tabel IV menunjukkan waktu (shift) yang digunakan untuk produksi komponen-komponen Isolating Cock pada tanggal 17 sampai 25 November 2014 dengan tanda ceklist.
TABEL III

UKURAN LOT TRANSFER BATCH EXISTING

\begin{tabular}{|c|c|c|c|c|c|}
\hline $\begin{array}{c}\text { Nama } \\
\text { Komponen }\end{array}$ & Proses & Operasi & $\begin{array}{c}\text { Sublot 1 } \\
\text { (unit) }\end{array}$ & $\begin{array}{c}\text { Sublot 2 } \\
\text { (unit) }\end{array}$ & $\begin{array}{c}\text { Sublot 3 } \\
\text { (unit) }\end{array}$ \\
\hline \multirow{5}{*}{ Rumah IC } & Bubut 1 & O-1A & 60 & - & - \\
\cline { 2 - 6 } & Bubut 2 & O-2A & 30 & 30 & - \\
\cline { 2 - 6 } & Bubut 3 & O-3A & 25 & 25 & 10 \\
\cline { 2 - 6 } & Bubut 4 & O-4A & 20 & 20 & 20 \\
\cline { 2 - 6 } & Bubut 5 & O-5A & 60 & - & - \\
\cline { 2 - 6 } & Bor & O-6A & 60 & - & - \\
\hline \multirow{5}{*}{ Flens } & Bubut 1 & O-1B & 60 & - & - \\
\cline { 2 - 6 } & Bubut 2 & O-2B & 60 & - & - \\
\cline { 2 - 6 } & Bor & O-3B & 60 & - & - \\
\cline { 2 - 6 } & Frais & O-4B & 60 & - & - \\
\hline \multirow{2}{*}{ Penutup } & Bubut 1 & O-1C & 60 & - & - \\
\cline { 2 - 6 } & Bubut 2 & O-2C & 60 & - & - \\
\hline Baut Ventilasi & Bubut 1 & O-1D & 60 & - & - \\
\hline
\end{tabular}

2. Penjadwalan Order Kondisi Usulan

a. Mengurutkan job menggunakan algoritma CDS

TABEL V

WAKTU PROSES DAN SETUP BENDA KERJA PADA MESIN

\begin{tabular}{|c|c|c|c|c|c|c|c|}
\hline \multirow{2}{*}{ Job i } & \multicolumn{6}{|c|}{ Waktu proses dan setup benda kerja pada mesin (menit) } \\
\cline { 2 - 8 } & L08 & L09 & L04 & L10 & L11 & D01 & M06 \\
\hline Rumah IC (A) & 17.78 & 6.58 & 12.19 & 13.73 & 11.21 & 27.16 & 0 \\
\hline Flens (B) & 0 & 0 & 8.47 & 0 & 19.32 & 11.64 & 2.42 \\
\hline Penutup (C) & 0 & 0 & 0 & 4.35 & 9.75 & 0 & 0 \\
\hline Baud Ventilasi (D) & 9.99 & 0 & 0 & 0 & 0 & 0 & 0 \\
\hline
\end{tabular}

Tabel $\mathrm{V}$ menunjukkan data yang digunakan untuk proses pengurutan job berdasarkan algoritma CDS. Waktu yang digunakan adalah waktu baku proses dan waktu setup benda kerja.

TABEL IV

PRODUKSI BULAN NOVEMBER 2014

\begin{tabular}{|c|c|c|c|c|c|c|c|c|c|c|c|c|c|c|c|c|c|c|c|c|c|c|}
\hline \multirow{3}{*}{ Komponen } & \multirow{3}{*}{ Proses } & \multirow{3}{*}{ Operasi } & \multirow{3}{*}{$\begin{array}{l}\text { Kode } \\
\text { Mesin }\end{array}$} & \multirow{3}{*}{$\begin{array}{c}\text { Tgl } \\
\text { Shift }\end{array}$} & \multicolumn{2}{|c|}{17} & \multicolumn{2}{|c|}{18} & \multicolumn{2}{|c|}{19} & \multicolumn{2}{|c|}{20} & \multicolumn{2}{|c|}{21} & \multicolumn{2}{|c|}{22} & \multicolumn{2}{|c|}{23} & \multicolumn{2}{|c|}{24} & \multirow{2}{*}{\multicolumn{2}{|c|}{25}} \\
\hline & & & & & & & & & & & & & & & & & & & & & & \\
\hline & & & & & 1 & 2 & 1 & 2 & 1 & 2 & 1 & 2 & 1 & 2 & 1 & 2 & 1 & 2 & 1 & 2 & 1 & 2 \\
\hline \multirow{6}{*}{ Rumah IC } & Bubut 1 & $\mathrm{O}-1 \mathrm{~A}$ & L08 & & $\sqrt{ }$ & $\sqrt{ }$ & $\sqrt{ }$ & $\sqrt{ }$ & & & & & & & & & & & & & & \\
\hline & Bubut 2 & $\mathrm{O}-2 \mathrm{~A}$ & L09 & & & & & & $\sqrt{ }$ & & & & & & & & & & & & & \\
\hline & Bubut 3 & O-3A & L04 & & & & & & $\sqrt{ }$ & $\sqrt{ }$ & $\sqrt{ }$ & & & & & & & & & & & \\
\hline & Bubut 4 & $\mathrm{O}-4 \mathrm{~A}$ & L10 & & & & & & & $\sqrt{ }$ & $\sqrt{ }$ & $\sqrt{ }$ & & & & & & & & & & \\
\hline & Bubut 5 & $\mathrm{O}-5 \mathrm{~A}$ & L11 & & & & & & & & $\sqrt{ }$ & $\sqrt{ }$ & $\sqrt{ }$ & & & & & & & & & \\
\hline & Bor & O-6A & D01 & & & & & & & & & & & $\sqrt{ }$ & $\sqrt{ }$ & $\sqrt{ }$ & $\sqrt{ }$ & $\sqrt{ }$ & $\sqrt{ }$ & & & \\
\hline \multirow{4}{*}{ Flens } & Bubut 1 & $\mathrm{O}-1 \mathrm{~B}$ & L04 & & & & & & & & & $\sqrt{ }$ & $\sqrt{ }$ & $\sqrt{ }$ & & & & & & & & \\
\hline & Bubut 2 & $\mathrm{O}-2 \mathrm{~B}$ & L10 & & & & & & & & & & & & $\sqrt{ }$ & $\sqrt{ }$ & $\sqrt{ }$ & & & & & \\
\hline & Bor & $\mathrm{O}-3 \mathrm{~B}$ & D01 & & & & & & & & & & & & & & & & & $\sqrt{ }$ & $\sqrt{ }$ & \\
\hline & Frais & $\mathrm{O}-4 \mathrm{~B}$ & M06 & & & & & & & & & & & & & & & & & & & $\sqrt{ }$ \\
\hline \multirow{2}{*}{ Penutup } & Bubut 1 & $\mathrm{O}-1 \mathrm{C}$ & L10 & & & & & $\sqrt{ }$ & $\sqrt{ }$ & & & & & & & & & & & & & \\
\hline & Bubut 2 & $\mathrm{O}-2 \mathrm{C}$ & L11 & & & & & & & $\sqrt{ }$ & $\sqrt{ }$ & $\sqrt{ }$ & & & & & & & & & & \\
\hline Baut V. & Bubut 1 & O-1D & L08 & & & & & & & & & & $\sqrt{ }$ & $\sqrt{ }$ & $\sqrt{ }$ & & & & & & & \\
\hline
\end{tabular}

Penjadwalan Produksi dengan Mempertimbangkan Ukuran Lot Transfer Batch untuk Minimasi 
Langkah 1 : Menghitung jumlah iterasi

Mesin yang digunakan untuk pengerjaan komponenkomponen Isolating Cock jumlahnya adalah tujuh mesin, terdiri dari lima mesin bubut, satu mesin bor, dan satu mesin frais.

$$
\mathrm{K}=\mathrm{m}-1=7-1=6
$$

$>$ Langkah 2 : Mengurutkan job

Mulai dari iterasi pertama $(\mathrm{k}=1)$, yaitu kombinasi antara dua kelompok mesin dengan setiap kelompoknya terdiri dari satu mesin. Kelompok mesin satu adalah mesin pertama, yaitu L08. Kelompok mesin dua adalah mesin ke tujuh, yaitu mesin M06. Selanjutnya membandingkan waktu antar komponen (job) pada kedua mesin tersebut. Tandai waktu yang terkecil antara dua mesin tersebut pada setiap job.

\begin{tabular}{|c|c|c|}
\hline \multicolumn{3}{|c|}{$\begin{array}{l}\text { TABEL VI } \\
\text { DATA K }=1\end{array}$} \\
\hline & \multicolumn{2}{|c|}{$\mathrm{k}=1$} \\
\hline & M1 (menit) & M2 (menit) \\
\hline$J o b$ i & L08 & M06 \\
\hline $\mathrm{A}$ & 17.78 & 10 \\
\hline $\mathrm{B}$ & (1) & 2.42 \\
\hline $\mathrm{C}$ & 0 & 0 \\
\hline $\mathrm{D}$ & 9.99 & 0 \\
\hline
\end{tabular}

Berdasarkan Tabel VI waktu terkecil untuk job A terletak pada M2. Waktu terkecil untuk job B terletak pada M1. Waktu terkecil untuk job C terletak pada M1 dan M2, karena nilainya sama maka pilih sembarang. Waktu terkecil untuk job D terletak pada M2. Kemudian mengurutkan job berdasarkan waktu terkecil. Semua watu terkecil menunjukkan angka nol (0), sehingga job yang dijadwalkan pertama adalah yang selisihnya paling sedikit antar job.

Selisih yang paling kecil adalah pada job $\mathrm{C}$ yaitu antara 0 dengan 0 sehingga selisihnya adalah 0 . Waktu terkecil telah dipilih pada M2, sehingga urutan jadwal untuk job $\mathrm{C}$ dilakukan di akhir (posisi nomer 4). Selisih terkecil selanjutnya setelah job $\mathrm{C}$ adalah job B yaitu antara 0 dengan 2,42 sehingga selisihnya adalah 2,42. Waktu terkecil terletak pada M1, sehingga urutan jadwal untuk job B dilakukan di awal (posisi nomer 1). Selisih terkecil selanjutnya setelah job B adalah job D yaitu antara 9,99 dengan 0, sehingga selisihnya adalah 9,99 . Waktu terkecil terletak pada M2, sehingga urutan jadwal untuk job D dilakukan di akhir sebelum job C (posisi nomer 3). Selisih terkecil selanjutnya setelah job D adalah job A yaitu antara 17,78 dengan 0 , sehingga selisihnya adalah 17,78 . Waktu terkecil terletak pada M2, sehingga urutan jadwal untuk job A dilakukan di akhir sebelum job D (posisi nomer 2). Oleh karena itu, hasil pengurutan job adalah B-A-D-C.
TABEL VII

HASIL URUTAN JOB

\begin{tabular}{|c|c|c|c|c|}
\hline \multirow{2}{*}{$\mathrm{k} i$} & \multicolumn{6}{|l|}{ Urutan $j o b$} \\
\hline & 1 & 2 & 3 & 4 \\
\hline $\mathrm{k}=1$ & $\mathrm{~B}$ & $\mathrm{~A}$ & $\mathrm{D}$ & $\mathrm{C}$ \\
\hline $\mathrm{k}=2$ & $\mathrm{~B}$ & $\mathrm{~A}$ & $\mathrm{D}$ & $\mathrm{C}$ \\
\hline $\mathrm{k}=3$ & $\mathrm{C}$ & $\mathrm{B}$ & $\mathrm{A}$ & $\mathrm{D}$ \\
\hline $\mathrm{k}=4$ & $\mathrm{C}$ & $\mathrm{B}$ & $\mathrm{A}$ & $\mathrm{D}$ \\
\hline $\mathrm{k}=5$ & $\mathrm{~B}$ & $\mathrm{~A}$ & $\mathrm{C}$ & $\mathrm{D}$ \\
\hline $\mathrm{k}=6$ & $\mathrm{~B}$ & $\mathrm{~A}$ & $\mathrm{C}$ & $\mathrm{D}$ \\
\hline
\end{tabular}$\quad$\begin{tabular}{|c|c|c|c|c|}
\hline \multirow{2}{*}{ Pilihan } & \multicolumn{3}{|c|}{ Urutan $j o b$} \\
\hline & 1 & 2 & 3 & 4 \\
\hline 1 & $\mathrm{~B}$ & $\mathrm{~A}$ & $\mathrm{D}$ & $\mathrm{C}$ \\
\hline 2 & $\mathrm{C}$ & $\mathrm{B}$ & $\mathrm{A}$ & $\mathrm{D}$ \\
\hline 3 & $\mathrm{~B}$ & $\mathrm{~A}$ & $\mathrm{C}$ & $\mathrm{D}$ \\
\hline
\end{tabular}

\begin{tabular}{|l|l|l|l|l|}
\hline $\mathrm{k}=6$ & $\mathrm{~B}$ & $\mathrm{~A}$ & $\mathrm{C}$ & $\mathrm{D}$ \\
\hline
\end{tabular}

Tabel VII menunjukkan urutan job yang sama dieliminasi sehingga menghasilkan tiga urutan job.

b. Menentukan Ukuran Lot

Divisi Tempa dan Cor bisa mengirimkan raw material setiap minggu. Order bulan Agustus-Desember 2014 adalah 1.200 unit. Dalam rentang tersebut terdapat 20 minggu. Pengiriman dari DEPSIN ke Departemen Assembly dilakukan setiap seminggu sekali. Ukuran lot pertama yang diusulkan berdasarkan target tiap minggu yaitu $1.200 \mathrm{unit} / 20 \mathrm{minggu}=60 \mathrm{unit} / \mathrm{minggu}$. Sehingga target tiap minggu adalah 60 unit produk Isolating Cock. Oleh karena itu, ukuran lot pertama adalah 60 unit. Ukuran lot kedua yang diusulkan berdasarkan target tiap hari yaitu 60 unit $/ 5$ hari $=12$ unit/hari. Target tiap minggu adalah 60 unit produk Isolating Cock, sehingga pengerjaan 12 unit/hari berulang lima kali. Oleh karena itu, ukuran lot kedua adalah 12 unit. Selanjutnya dihitung ukuran sublot untuk masing-masing komponen Isolating Cock. Penjadwalan dilakukan dengan membandingkan makespan antara ukuran lot batch dengan ukuran lot transfer batch.

\section{Komponen Flens}

Data waktu pengerjaan komponen Flens pada setiap prosesnya adalah $\mathrm{P} 1=8,47$ menit, $\mathrm{P} 2=19,32$ menit, $\mathrm{P} 3$ $=11,64$ menit, dan $\mathrm{P} 4=2,42$ menit. Selanjutnya tetapkan bahwa $\mathrm{u}=1$. Kemudian mencari nilai $\mathrm{v}_{\mathrm{i}}$. Nilai $\mathrm{v}$ dicari mulai dari $\mathrm{v}_{2}$ [4].

a. Menghasilkan pemecahan dasar

$>$ Langkah 1: Set $\mathrm{u}=1$ dan letakkan mesin pertama pada pemecahan

Selanjutnya tetapkan bahwa $\mathrm{u}=1$.

$$
\mathrm{u}=1
$$

$>$ Langkah 2: Temukan $\max _{\mathrm{v}>\mathrm{u}}\left\{\mathrm{q}_{\mathrm{uv}}\right\}$

Kemudian mencari nilai $\mathrm{v}_{\mathrm{i}}$. Nilai $\mathrm{v}$ dicari mulai dari $\mathrm{v}_{2}$.

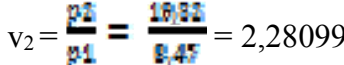

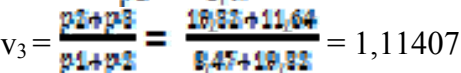

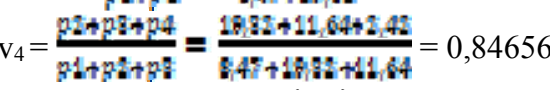

$$
\begin{aligned}
& \max _{\mathrm{v}>\mathrm{u}}\left\{\mathrm{q}_{\mathrm{uv}}\right\}
\end{aligned}
$$

nilai $\mathrm{v}$ maksimum berada pada $\mathrm{v}=2 \neq \mathrm{m}$

$$
\mathrm{q}[1][2]=\mathrm{q} 12=2,28099
$$


Nilai $\mathrm{m}$ adalah 4 karena komponen Flens dikerjakan oleh 4 mesin. Proses perhitungan nilai $\mathrm{v}$ berhenti jika nilai $\mathrm{v}$ maksimal terletak pada $\mathrm{V}_{\mathrm{m}}$. Perolehan nilai $\mathrm{v}$ maksimal belum terletak pada $\mathrm{v}_{4}$, sehingga perhitungan $\mathrm{v}$ dilanjutkan pada $\mathrm{u}=2$.

$>$ Langkah 3: Tambahkan mesin $\mathrm{v}$ ke pemecahan setelah mesin $\mathrm{u}$. Bila $\mathrm{v}=\mathrm{m}$, berhenti. Mulai $\mathrm{u}=\mathrm{v}$ dan kembali ke langkah 2.

Selanjutnya tetapkan bahwa $\mathrm{u}=2$. Kemudian mencari nilai $\mathrm{v}_{\mathrm{i}}$. Nilai $\mathrm{v}$ dicari mulai dari $\mathrm{v}_{3}$.

$$
\begin{aligned}
& \mathrm{u}=2
\end{aligned}
$$

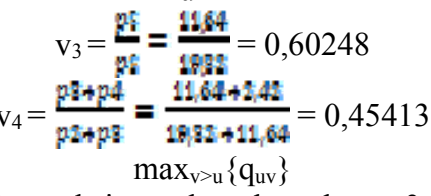

nilai $\mathrm{v}$ maksimum berada pada $\mathrm{v}=3 \neq \mathrm{m}$

$$
\mathrm{q}[2][3]=\mathrm{q} 23=0,60248
$$

Nilai m adalah 4 karena komponen Flens dikerjakan oleh 4 mesin. Proses perhitungan nilai v berhenti jika nilai $\mathrm{v}$ maksimal terletak pada $\mathrm{V}_{\mathrm{m}}$. Perolehan nilai $\mathrm{v}$ maksimal belum terletak pada $\mathrm{V}_{4}$, sehingga perhitungan $\mathrm{v}$ dilanjutkan pada $\mathrm{u}=3$.

Selanjutnya tetapkan bahwa $\mathrm{u}=3$. Kemudian mencari nilai $\mathrm{v}_{\mathrm{i}}$. Nilai $\mathrm{v}$ dicari mulai dari $\mathrm{v}_{4}$.

$$
\begin{gathered}
\mathrm{v}_{4}=\frac{\mathrm{p}=3}{\mathrm{p} !}=\frac{\mathrm{i:42}}{11,64}=0,2079 \\
\max _{\mathrm{v}>\mathrm{u}}\left\{\mathrm{q}_{\mathrm{uv}}\right\}
\end{gathered}
$$

nilai $\mathrm{v}$ maksimum berada pada $\mathrm{v}=4=\mathrm{m}$

$$
\mathrm{q}[3][4]=\mathrm{q} 24=0,2079
$$

b. Solusi untuk sublot konsisten $(\mathrm{s}=2)$

$>$ Langkah 1 : Temukan pecahan dasar dan mulai $\mathrm{u}=2$ Selanjutnya tetapkan bahwa $\mathrm{u}=2$.

$$
\mathrm{u}=2
$$

Langkah 2 : Bila $[\mathrm{u}]=\mathrm{m}($ mesin $[\mathrm{u}]$ adalah mesin terakhir dalam pemecahan), lanjut ke langkah 4

$$
\mathrm{u}=2 \neq \mathrm{m}
$$

maka lanjut ke langkah 3

$>$ Langkah 3 : Bila $\mathrm{P}(1,[\mathrm{u}]-1) \leq \mathrm{P}([\mathrm{u}]+1, \mathrm{~m})$, mulai $\mathrm{u}=\mathrm{u}+1$ dan kembali ke langkah 2

$$
\begin{gathered}
\mathrm{u}=2 \\
\mathrm{P}(1,[\mathrm{u}]-1) \leq \mathrm{P}([\mathrm{u}]+1, \mathrm{~m}) \\
\mathrm{P}(1,[2]-1) \leq \mathrm{P}([2]+1,4), \\
\mathrm{P}(1,1) \leq \mathrm{P}(3,4), \\
8.47 \leq[(11.64+2.42)=14.06] \\
\mathrm{u}=3 \\
\mathrm{P}(1,[\mathrm{u}]-1) \leq \mathrm{P}([\mathrm{u}]+1, \mathrm{~m}) \\
\mathrm{P}(1,[3]-1) \leq \mathrm{P}([3]+1,4), \\
\mathrm{P}(1,2) \leq \mathrm{P}(4,4),
\end{gathered}
$$

$$
[(8.47+19.32)=27.79] \leq 2.42
$$

Langkah 4 : Mulai $\mathrm{L}_{1}=\mathrm{U} /\left(1+\mathrm{q}_{[\mathrm{u}-1][\mathrm{u}]}\right)$ dan $\mathrm{L}_{2}=\mathrm{U}-\mathrm{L}_{1}$

$$
\mathrm{q}[3][4]=\mathrm{q} 24=0,2079
$$

Untuk ukuran lot batch pertama 60 unit / minggu :

$$
\begin{gathered}
\mathrm{U}=60 \text { unit } \\
\mathrm{L}_{1}=\mathrm{U} /\left(1+\mathrm{q}_{[\mathrm{u}-1][\mathrm{u}]}\right)=\frac{60}{(1+9,2059)}=49 \text { unit } \\
\mathrm{L}_{2}=\mathrm{U}-\mathrm{L}_{1}=60-49=11 \text { unit }
\end{gathered}
$$

Untuk ukuran lot batch kedua 12 unit / hari :

$$
\begin{gathered}
\mathrm{U}=12 \text { unit } \\
\mathrm{L}_{1}=\mathrm{U} /\left(1+\mathrm{q}_{[\mathrm{u}-1][\mathrm{u}]}\right)=\frac{12}{(1+1,1 \mathrm{R}:)}=9 \text { unit } \\
\mathrm{L}_{2}=\mathrm{U}-\mathrm{L}_{1}=12-9=3 \text { unit }
\end{gathered}
$$

Hasil perhitungan lot transfer batch usulan pertama dan kedua dapat dilihat pada Tabel VIII.

TABEL VIII

USULAN UKURAN LOT TRANSFER BATCH

\begin{tabular}{|c|c|c|c|c|c|c|}
\hline \multirow{3}{*}{$\begin{array}{c}\text { Nama } \\
\text { Komponen }\end{array}$} & \multirow{2}{*}{ Proses } & \multirow{2}{*}{ Operasi } & \multicolumn{2}{|c|}{ Usulan 1 } & \multicolumn{2}{c|}{ Usulan 2 } \\
\cline { 4 - 7 } & & & Sublot 1 & Sublot 2 & Sublot 1 & Sublot 2 \\
\cline { 3 - 7 } & & (unit) & (unit) & (unit) & (unit) \\
\hline \multirow{5}{*}{ Rumah IC } & Bubut 1 & O-1A & 28 & 32 & 6 & 6 \\
\cline { 2 - 7 } & Bubut 2 & O-2A & 28 & 32 & 6 & 6 \\
\cline { 2 - 7 } & Bubut 3 & O-3A & 28 & 32 & 6 & 6 \\
\cline { 2 - 7 } & Bubut 4 & O-4A & 28 & 32 & 6 & 6 \\
\cline { 2 - 7 } & Bubut 5 & O-5A & 28 & 32 & 6 & 6 \\
\cline { 2 - 7 } & Bor & O-6A & 28 & 32 & 6 & 6 \\
\hline \multirow{5}{*}{ Flens } & Bubut 1 & O-1B & 49 & 11 & 9 & 3 \\
\cline { 2 - 7 } & Bubut 2 & O-2B & 49 & 11 & 9 & 3 \\
\cline { 2 - 7 } & Bor & O-3B & 49 & 11 & 9 & 3 \\
\cline { 2 - 7 } & Frais & O-4B & 49 & 11 & 9 & 3 \\
\hline \multirow{3}{*}{ Penutup } & Bubut 1 & O-1C & 19 & 41 & 4 & 8 \\
\cline { 2 - 7 } & Bubut 2 & O-2C & 19 & 41 & 4 & 8 \\
\hline Baut Ventilasi & Bubut 1 & O-1D & 60 & - & 12 & - \\
\hline
\end{tabular}

Proses pengurutan job menggunakan algoritma CDS digunakan untuk menjadwalkan komponen-komponen Isolating Cock dengan ukuran lot transfer batch, yaitu produk ditransfer ke mesin berikutnya ketika tiap sublot selesai dikerjakan pada mesin tertentu. A adalah Rumah IC, B adalah Flens, C adalah Penutup, dan D adalah Baut Ventilasi. Bila menggunakan ukuran lot transfer batch usulan pertama, maka makespan untuk 60 unit buah produk Isolating Cock dengan urutan B-A-D-C dan B-A-C-D adalah sama yaitu 3.701,81 menit $=61,7$ jam atau 10 shift kerja, sedangkan makespan dengan urutan C-B-A-D adalah 3.954,08 menit $=65,9$ jam atau 11 shift kerja. Bila menggunakan ukuran lot transfer batch usulan kedua, maka makespan untuk 60 unit buah produk Isolating Cock dengan urutan B-A-D-C dan B-A-C-D adalah sama yaitu 2.781,5 menit $=46,4$ jam atau 8 shift kerja, sedangkan makespan dengan urutan C-B-A-D adalah 2.749,3 menit $=45,8$ jam atau 8 shift kerja. Durasi waktu pengerjaan komponen-komponen Isolating Cock dengan ukuran lot transfer batch usulan pertama dapat dilihat pada Tabel IX dan 
usulan kedua pada Tabel X. Waktu setup benda kerja dan waktu proses telah dikalikan dengan jumlah benda yang dikerjakan pada sublot tersebut. Gannt chart untuk usulan pertama dapat dilihat pada Gambar 3 dan usulan kedua pada Gambar 4.

\section{A. Analisis Penjadwalan Order Kondisi Existing}

Penjadwalan yang saat ini dilakukan oleh Planner bagian PPIC PT PINDAD mengacu pada kedatangan order yang pertama atau disebut FCFS. Berdasarkan penjadwalan bulan November dengan ukuran lot sesuai kondisi existing, maka makespan untuk 60 unit produk Isolating Cock bisa dikirim ke Departemen Assembly dengan waktu produksi sebesar 18 shift kerja. Durasi penyelesaian pekerjaan ini berpengaruh pada
Departemen Assembly karena komponen-komponen Isolating Cock akan dirakit. Setiap order memiliki waktu pengerjaan yang berbeda-beda sehingga ketika Planner tidak tepat mempertimbangkan pengurutan order yang dikerjakan, maka berdampak pada waktu pengerjaan dapat lebih lama. Ketika order komponen Baut Ventilasi datang lebih awal daripada komponen Rumah IC, maka operasi yang dilakukan pertama adalah O-1D atau proses Bubut 1 pada komponen Baut Ventilasi. Sehingga menyebabkan operasi O-1A atau proses Bubut 1 pada komponen Rumah IC ditunda karena menggunakan mesin yang sama. Padahal penyelesaian komponen Rumah IC yang paling berat karena melalui proses yang lebih banyak daripada komponen yang lain.

TABEL IX

DURASi PENGERJAAN PENJAdWALAN DENGAN UKURAN LOT TRANSFER BATCH USUlan PERTAMA

\begin{tabular}{|c|c|c|c|c|c|c|c|c|c|}
\hline \multirow[b]{2}{*}{$J o b$} & \multirow[b]{2}{*}{$\begin{array}{l}\text { Kode } \\
\text { Mesin }\end{array}$} & \multirow[b]{2}{*}{$\begin{array}{l}\text { Setup } \\
\text { fixture } \\
\text { (menit) }\end{array}$} & \multirow[b]{2}{*}{$\begin{array}{l}\text { Setup } \\
\text { tools } \\
\text { (menit) }\end{array}$} & \multicolumn{3}{|c|}{ Sublot 1} & \multicolumn{3}{|c|}{ Sublot 2} \\
\hline & & & & $\begin{array}{l}\text { Setup benda } \\
\text { kerja } \\
\text { (menit) }\end{array}$ & $\begin{array}{l}\text { Waktu } \\
\text { Proses } \\
\text { (menit) }\end{array}$ & $\begin{array}{c}\text { Total } \\
\text { Waktu } \\
\text { (menit) }\end{array}$ & $\begin{array}{c}\text { Setup benda } \\
\text { kerja } \\
\text { (menit) }\end{array}$ & $\begin{array}{l}\text { Waktu } \\
\text { Proses } \\
\text { (menit) }\end{array}$ & $\begin{array}{c}\text { Total } \\
\text { Waktu } \\
\text { (menit) }\end{array}$ \\
\hline $\mathrm{C}$ & L10 & - & 0.7 & 19.95 & 62.7 & 83.35 & 43.05 & 135.3 & 178.35 \\
\hline $\mathrm{C}$ & L11 & - & 2.9 & 20.9 & 164.35 & 188.15 & 45.1 & 354.65 & 399.75 \\
\hline $\mathrm{B}$ & L04 & 2.95 & 1 & 149.45 & 265.58 & 418.98 & 33.55 & 59.62 & 93.17 \\
\hline B & L10 & 2.95 & 3.9 & 149.45 & 797.23 & 953.53 & 33.55 & 178.97 & 212.52 \\
\hline $\mathrm{B}$ & D01 & 0.3 & 0.35 & 46.55 & 523.81 & 571.01 & 10.45 & 117.59 & 128.04 \\
\hline B & M06 & 0.3 & 0.6 & 46.55 & 72.03 & 119.48 & 10.45 & 16.17 & 26.62 \\
\hline $\mathrm{A}$ & L08 & 6.15 & 3.1 & 85.4 & 412.44 & 507.09 & 97.6 & 471.36 & 568.96 \\
\hline A & L09 & 2.95 & 0.8 & 86.8 & 97.44 & 187.99 & 99.2 & 111.36 & 210.56 \\
\hline A & L04 & 2.95 & 2.8 & 86.8 & 254.52 & 347.07 & 99.2 & 290.88 & 390.08 \\
\hline $\mathrm{A}$ & L10 & 2.95 & 3.7 & 86.8 & 297.64 & 391.09 & 99.2 & 340.16 & 439.36 \\
\hline A & L11 & 2.95 & 2.9 & 86.8 & 227.08 & 319.73 & 99.2 & 259.52 & 358.72 \\
\hline $\mathrm{D}$ & L08 & 2.95 & 3 & 183 & 416.4 & 605.35 & - & - & - \\
\hline
\end{tabular}

\section{B. Analisis Ukuran Lot Transfer Batch}

Setiap komponen memiliki waktu pengerjaan yang berbeda-beda sehingga ketika operator tidak tepat mempertimbangkan jumlah ukuran lot transfer batch yang dipindahkan, maka berdampak pada waktu pengerjaan. Waktu pengerjaan sangat bergantung pada waktu penyelesaian komponen Rumah IC karena komponen tersebut memiliki operasi yang lebih banyak daripada komponen lainnya. Sehingga ukuran lot transfer batch komponen Rumah IC sangat berpengaruh. Semakin besar jumlah sublot komponen Rumah IC, maka semakin lama proses pada mesin yang digunakan dan menyebabkan idle pada mesin selanjutnya.
C. Analisis Penjadwalan Order Usulan

1. Analisis Algoritma CDS

Penjadwalan produksi yang diusulkan adalah penjadwalan flow shop dengan algoritma CDS untuk meminimasi makespan pengerjaan komponen-komponen Isolating Cock karena berpengaruh terhadap waktu pengiriman produk ke Departemen Assembly. Penjadwalan mempertimbangkan urutan pengerjaan komponen dan ukuran lot transfer batch. Penjadwalan dengan algoritma CDS menghasilkan tiga urutan job yang berbeda, namun untuk urutan job B-A-C-D dan B-A-D-C menghasilkan gantt chart dan makespan yang sama karena job $\mathrm{C}$ (Penutup) dan job D (Baut Ventilasi) tidak dikerjakan dalam mesin yang sama sehingga keduanya tidak bergantung satu sama lain. 


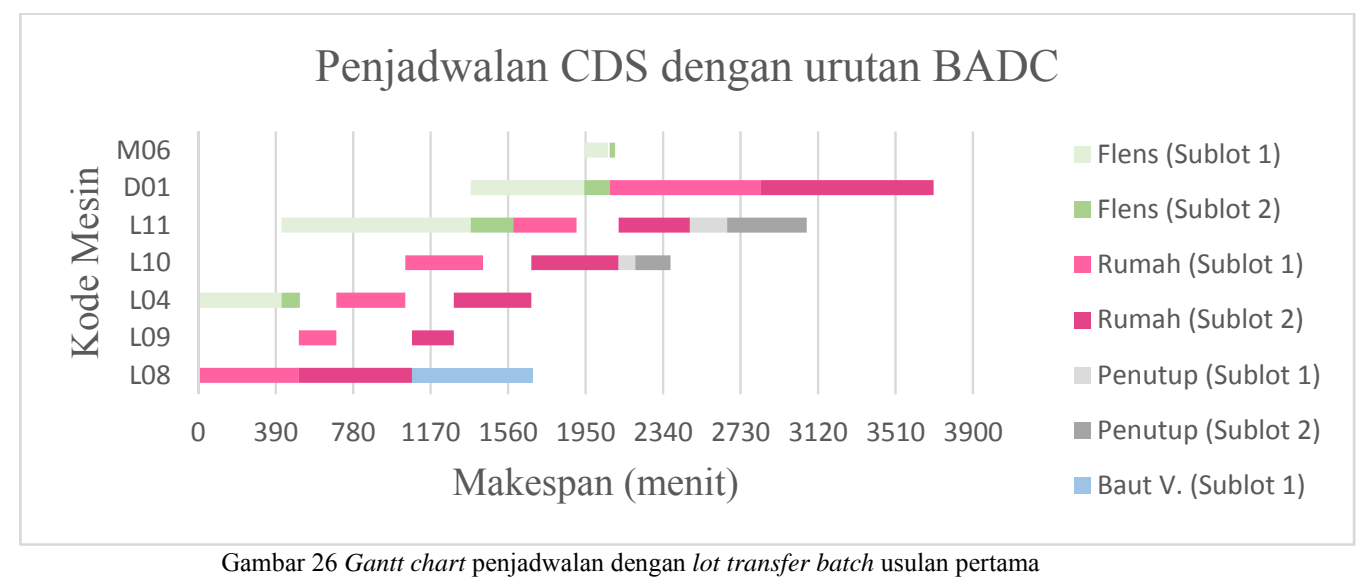

TABEL X

DURASI PENGERJAAN PENJADWALAN DENGAN UKURAN LOT TRANSFER BATCH USULAN KEDUA

\begin{tabular}{|c|c|c|c|c|c|c|c|c|c|}
\hline \multirow[b]{2}{*}{$J o b$} & \multirow[b]{2}{*}{$\begin{array}{l}\text { Kode } \\
\text { Mesin }\end{array}$} & \multirow[b]{2}{*}{$\begin{array}{l}\text { Setup } \\
\text { fixture } \\
\text { (menit) }\end{array}$} & \multirow[b]{2}{*}{$\begin{array}{l}\text { Setup } \\
\text { tools } \\
\text { (menit) }\end{array}$} & \multicolumn{3}{|c|}{ Sublot 1} & \multicolumn{3}{|c|}{ Sublot 2} \\
\hline & & & & $\begin{array}{c}\text { Setup benda } \\
\text { kerja } \\
\text { (menit) }\end{array}$ & $\begin{array}{l}\text { Waktu } \\
\text { Proses } \\
\text { (menit) }\end{array}$ & $\begin{array}{l}\text { Total } \\
\text { Waktu } \\
\text { (menit) }\end{array}$ & $\begin{array}{c}\text { Setup benda } \\
\text { kerja } \\
\text { (menit) }\end{array}$ & $\begin{array}{l}\text { Waktu } \\
\text { Proses } \\
\text { (menit) }\end{array}$ & $\begin{array}{c}\text { Total } \\
\text { Waktu } \\
\text { (menit) }\end{array}$ \\
\hline $\mathrm{C}$ & L10 & - & 0.7 & 4.2 & 13.2 & 18.1 & 8.4 & 26.4 & 34.8 \\
\hline $\mathrm{C}$ & L11 & - & 2.9 & 4.4 & 34.6 & 41.9 & 8.8 & 69.2 & 78 \\
\hline B & L04 & 2.95 & 1 & 27.45 & 48.78 & 80.18 & 9.15 & 16.26 & 25.41 \\
\hline $\mathrm{B}$ & L10 & 2.95 & 3.9 & 27.45 & 146.43 & 180.73 & 9.15 & 48.81 & 57.96 \\
\hline $\mathrm{B}$ & D01 & 0.3 & 0.35 & 8.55 & 96.21 & 105.41 & 2.85 & 32.07 & 34.92 \\
\hline $\mathrm{B}$ & M06 & 0.3 & 0.6 & 8.55 & 13.23 & 22.68 & 2.85 & 4.41 & 7.26 \\
\hline A & L08 & 6.15 & 3.1 & 18.3 & 88.38 & 115.93 & 18.3 & 88.38 & 106.68 \\
\hline A & L09 & 2.95 & 0.8 & 18.6 & 20.88 & 43.23 & 18.6 & 20.88 & 39.48 \\
\hline A & L04 & 2.95 & 2.8 & 18.6 & 54.54 & 78.89 & 18.6 & 54.54 & 73.14 \\
\hline A & L10 & 2.95 & 3.7 & 18.6 & 63.78 & 89.03 & 18.6 & 63.78 & 82.38 \\
\hline A & L11 & 2.95 & 2.9 & 18.6 & 48.66 & 73.11 & 99.2 & 48.66 & 147.86 \\
\hline $\mathrm{D}$ & L08 & 2.95 & 3 & 36.6 & 83.28 & 125.83 & - & - & - \\
\hline
\end{tabular}

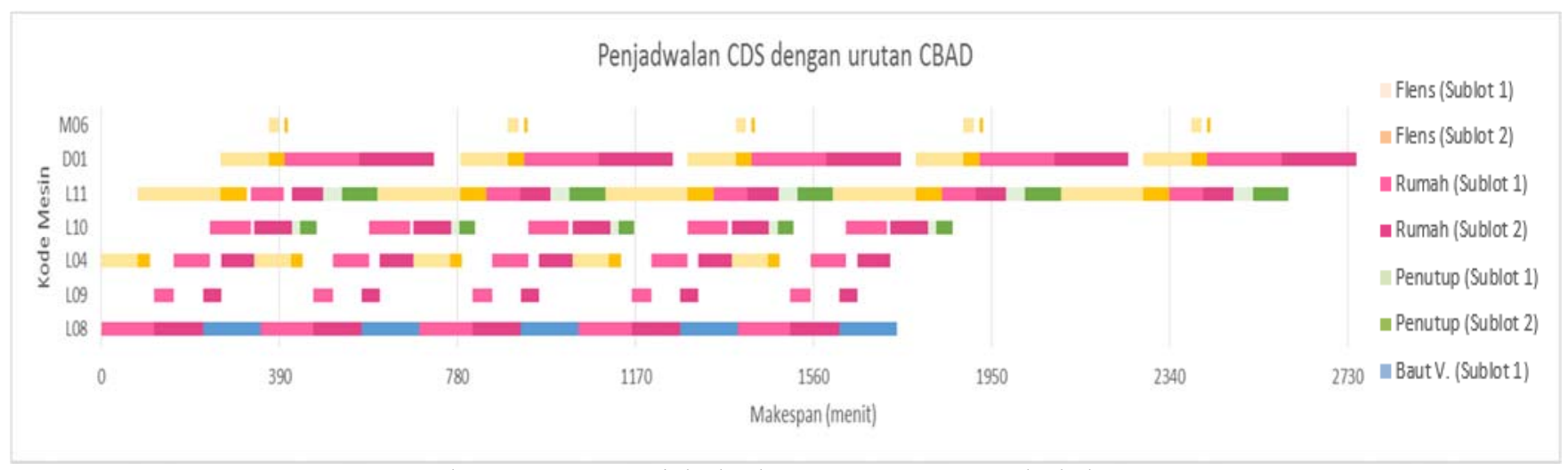

Gambar 27 Gantt chart penjadwalan dengan lot transfer batch usulan kedua

Penjadwalan Produksi dengan Mempertimbangkan Ukuran Lot Transfer Batch untuk Minimasi 
2. Analisis Penjadwalan tanpa

Penjadwalan untuk ukuran batch 60 unit produk Isolating Cock tanpa ukuran lot transfer batch menggunakan algoritma CDS dengan urutan job B-A-D-C, C-B-A-D, dan B-A-C-D menghasilkan makespan yang sama yaitu 5.350,9 menit. Penjadwalan tanpa penentuan ukuran lot transfer batch memiliki makespan yang lebih besar daripada penjadwalan dengan penentuan ukuran lot transfer batch. Hal tersebut berpengaruh terhadap banyaknya shift kerja operator untuk menyelesaikan produk Isolating Cock. Makespan menjadi lebih panjang karena terjadi waiting dari proses yang sedang berlangsung ke proses selanjutnya. Produksi 60 unit Isolating Cock membutuhkan setup fixture dan setup tools sebanyak satu kali, dan setup benda kerja sebanyak 60 kali.

3. Analisis Ukuran Lot Transfer Batch Usulan

Ukuran lot yang dihitung terdiri dari dua usulan, yaitu 60 unit dan 12 unit. Pada usulan pertama menghasilkan makespan yang lebih besar karena masih terjadi idle pada semua mesin, kecuali L08. Produksi 60 unit Isolating Cock membutuhkan setup fixture dan setup tools sebanyak satu kali, dan setup benda kerja sebanyak 60 kali. Sedangkan pada usulan kedua, yaitu mengerjakan tiap 12 unit produk selama lima kali sehingga jumlah akhirnya 60 unit dalam seminggu, menghasilkan makespan yang lebih kecil karena pada mesin L08 dan L11 tidak terjadi idle. Produksi 60 unit Isolating Cock membutuhkan setup fixture dan setup tools sebanyak lima kali, dan setup benda kerja sebanyak 60 kali.

\section{KESIMPULAN}

Penjadwalan komponen-komponen Isolating Cock pada bulan Agustus-Desember 2014 menggunakan algoritma CDS urutan job C-B-A-D (Penutup-Flens-Rumah IC-Baut Ventilasi) dan ukuran lot batch 12 unit diulang sebanyak lima kali (60 unit) dengan pengaturan lot transfer batch pada komponen Rumah IC sublot satu 6 unit dan sublot dua 6 unit, komponen Flens sublot satu 9 unit dan sublot dua 3 unit, komponen Penutup sublot satu 4 unit dan sublot dua 8 unit, serta komponen Baut Ventilasi sublot satu 12 unit, dapat meminimasi makespan dari 117 jam atau 18 shift kerja menjadi adalah 2.749,3 menit $=45,8$ jam atau 8 shift sehingga menghemat waktu penyelesaian sebesar $60,85 \%$.

\section{DAFTAR PUSTAKA}

[1] www.pindad.com. (2014, November 25). Diambil kembali dari www.pindad.com : www.pindad.com/industrialmachinery-and-services

[2] Ginting, R. (2009). Penjadwalan Mesin. Yogyakarta: Graha Ilmu.

[3] Nicholas, J. M. (1998). Competitive Manufacturing Management: Continuous Improvement, Lean Production, Customer-Focused Quality. Singapore: McGraw-Hill.
[4] Baker, K. R., \& Trietsch, D. (2009). Principles of Sequencing and Scheduling. Canada: John Wiley \& Sons Inc. 